\title{
Localization and Sorting of Mast Cells in Human Ovary; A Histological and Immunohistochemical Study
}

\author{
Sahar M Gamal, Nadia M Al- Rouby, and Mohammad A Ali \\ Histology Department, Faculty of Medicine, Cairo University
}

\begin{abstract}
:
Background: In human, mast cells (MCs) are classified according to their proteases' content into tryptase-containing mast cells $\left(\mathrm{MC}_{\mathrm{T}}\right)$ and tryptase and chymase-containing mast cells $\left(\mathrm{MC}_{\mathrm{TC}}\right)$. In addition to phenotypic differences in $\mathrm{MC}$ subtypes, there is also functional distributional heterogeneity. The present study was carried out to determine the physiological distribution of mast cells in the different components of human ovary of different age groups. Mast cell sorting according to their proteases content was also attempted with special emphasis on the possible mechanism of their effects on ovarian functions. Material and methods: Archival blocks of human ovarian tissue from females with age ranging from 16 to 75 years were used. The specimens were divided into reproductive- and postmenopausal-age groups. Histological study using haematoxylin and eosin as well as Masson trichrome staining was performed. Immunostaining using monoclonal antibodies against tryptase and chymase was also carried out. Morphometric measurements in the form of mast cell count per high power field as well as optical density of positively immuno-stained mast cells in addition to measurement of area and area per cent were done. Obtained data were statistically analyzed for significance using student's T- test. Results: MCs were mainly found in the deep cortical stroma and in the vicinity of blood vessels. Occasionally, few cells were found in the corpora lutea. There were no immunostained MCs in the walls of the different ovarian follicles, corpora albicans or in the periphery of the ovarian cortical stroma. Statistical analysis revealed that the number of $\mathrm{MC}_{\mathrm{T}}$ was significantly higher than $\mathrm{MC}_{\mathrm{TC}}$ in the reproductive-age group in comparison to the postmenopausal-age group. The postmenopausal-age group demonstrated the presence of statistically significant more degranulated $\mathrm{MC}_{\mathrm{TC}}$ and high collagen content in comparison to the reproductive-age group. Conclusion: MC subtypes follow specific distribution pattern within the ovarian tissue in the different age groups which has an impact on different ovarian functions in many physiological and pathological situations.
\end{abstract}

Key Words: Mast cells, age, tryptase, chymase, immunohistochemistry and ovary.

\section{Introduction:}

Mast cells (MCs) are commonly found in the connective tissue or in the mucosa of many organs including skin, airways, digestive tract, testis, epididymis and female reproductive system (Metcalfe $\boldsymbol{e t}$ al., 1997; Yong, 1997; Weidinger et al., 2003 and Karaca et al., 2007). In species with a well developed ovarian cortical stroma and a long oestrous cycle, mast cells were found to reside in the cortex and medulla of the ovary (Reibiger and Spanel- Borowski, 2000).

MCs develop from bone marrow derived progenitor cells that enter the tissue through the blood circulation (Benoist and Mathis, 2002). Unlike basophils or eosinophils, MCs do not leave the bone marrow as mature cells but as committed progenitors that lack secretory granules and, ultimately, functions characteristic of MC (Rodewald et al., 1996). Upon reaching peripheral tissues, committed progenitors differentiate under the influence of micro-environmental factors to morphologically and functionally mature MCs. Maturation of MCs is accompanied by a change in their chemokine receptor profile (Forsythe \& Befus, 2003).

MCs are one of the major effector cells in the pathogenesis of the immediate-type 
hypersensitivity reaction in a number of non-allergic immune disorders as well as in normal physiological processes. Moreover, some studies have shown that human MCs were involved in activation of fibroblasts and promotion of collagen synthesis by producing and releasing fibrogenic substances. Hence MCs could play a role in the pathogenesis of chronic inflammations and fibrosis (Feldmann et al., 1996 and Gurber et al., 1997). The effects of MCs are thought to be mediated by soluble substances, namely biogenic amines, proteoglycans, prostaglandins and neutral proteases (Malaviya and Georges, 2002).

In human, the strict classification of $\mathrm{MCs}$ into mucosal and connective tissue subtypes is not practically possible. Alternatively, the content of mast cellspecific proteases; namely chymase and tryptase, is the main criterion for human MC subtyping. The large quantities of tryptase and chymase that are synthesized by MCs suggest and emphasize the significance of these proteases on $\mathrm{MC}$ functions (Weidinger et al., 2003). Cells that contain tryptase alone are designated $\mathrm{MC}_{\mathrm{T}}$, whereas cells that contain both tryptase and chymase are designated $\mathrm{MC}_{\mathrm{TC}}$ and are predominantly associated with the connective tissue. Moreover, the two MCs phenotypes are also heterogenous with respect to their content of certain cytokines. Inter-leukin-4 (IL-4) is expressed preferentially by $\mathrm{MC}_{\mathrm{TC}}$ while, IL-5 and IL-6 are restricted almost exclusively to $\mathrm{MC}_{\mathrm{T}}$ (Bradding et al., 1995). In addition to phenotypic differences in MC subtypes, there is also functional heterogeneity which suggests that the cells modify their characteristics on an organ-and/or tissue-specific basis (Forsythe \& Ennis, 2000).

Until recently, MCs have been viewed primarily as harmful effector cells of allergic and potentially lethal anaphylactic reactions. The evidences for more effective role of MC are accumulating. So, the present study was carried out to determine the physiological distribution of mast cells in the different components of human ovary of different age groups. Mast cells' sorting according to their proteases content was also attempted with special emphasis on the possible mechanism of their effects on the ovarian functions.

\section{Material and Methods:}

\section{Ovarian Tissue:}

Human ovarian tissue blocks were obtained from females of different ages ranging from 16-75 years without revealing the identity of those patients during the period from 2005 to 2007. Specimen blocks belonged to females treated by hysterectomy with bilateral salpingooophorectomy for early stages of cervical and uterine cancer (Pathology Department, National Cancer Institute, Cairo University). The rest of the blocks were supplied by the Pathology Laboratory of Forensic Medicine Department, Ministry of Justice, Cairo. All specimens studied in this work were used with permission of the concerned department.

Thirty samples of ovarian tissue were collected and divided into two groups:

Group I (Reproductive-age group): included 15 samples from females within the age range of 16 to 50 years (mean = 31.6).

Group II (Postmenopausal-age group): included 15 specimens from older females ranging from 55-75 years $($ mean $=61.9)$.

\section{Histological study:}

Sections of $5 \mu \mathrm{m}$ thickness from all subjects' blocks were cut then stained with hematoxylin and eosin for the histological study as well as Masson trichrome for detection of collagen fibers (Drury and Wallington, 1967). They were screened to exclude any histological deviation from normal ovarian structure prior to usage in this study. Masson trichrome stained slides were examined to assess the amount of collagen fibers of the C.T. stroma. 


\section{Immunohistochemical study:}

Since tryptase is produced by both subtypes of MCs, identification of total MCs in human ovarian tissue was done using immunohistochemical staining for tryptase, by a mouse monoclonal antibody (Ab-2, Clone AA1, Neomarkers, USA). Identification of the other subclass $\mathrm{MC}_{\mathrm{TC}}$ was achieved by using a mouse monoclonal antibody targeting chymase (Ab-1, Clone CC1, Neomarkers, USA). Ovarian tissue sections were mounted on positively charged slides then deparaffinized in xylene, rehydrated through ethanol series and rinsed in phosphate buffer saline (PBS) of pH 7.2. Heat induced epitope retrieval was done in $10 \mathrm{mM}$ sodium citrate buffer of $\mathrm{pH} 6$ for $20 \mathrm{~min}$ followed by cooling at room temperature for another $20 \mathrm{~min}$. Primary antibodies were then added to the slides (optimal dilution 1:10 in distilled water) and the slides were then incubated for 60 min in moist chamber at room temperature.

A ready to use detection system (biotinylated secondary antibody) was applied for $10 \mathrm{~min}$ followed by strepavidin label for $20 \mathrm{~min}$. The final colouring agent was diaminobenzidine which was used for $10 \mathrm{~min}$ until a desirable brown colour was obtained (Meineke et al., 2000). Immunodetection of $\mathrm{MC}_{\mathrm{T}}$ was employed as this marker used to identify both degranulated as well as intact MCs (Samoszuk et al., 2005). Immunostaining for tryptase was clearly visible as brown deposits within intact mast cells and as highly localized extracellular granular material.

\section{Morphometric study}

Morphometric measurements of digitalized images from stained sections were performed by "Leica QWin 500" image analyzer computer system (England) and a Zeiss light microscope (Germany) using a magnification of $\mathrm{x} 400$. The image analyzer was first calibrated automatically to convert the measurement units (pixels) produced by the image analyzer program into actual micrometer units. In each specimen ten readings were obtained and the mean values and standard deviations were calculated automatically by the image analyser. Quantitative morphometric study included:

- Measurment of the area and area $\%$ of the blue stained collagen fibers in Masson trichrome stained sections of both groups. The area \% was calculated relative to a standard measuring frame of a standard area. In each chosen field the tissue to be measured was enclosed inside the standard measuring frame and then the blue stained areas of collagen were masked by a blue binary color. Then the software was asked to calculate the area\% of the blue binary color relative to the area of the measuring frame.

- Counting of mast cell number per high power field: cells positive for tryptase were counted as total number of positively stained MCs/high power field. The cells positive for chymase were counted as the number of $\mathrm{MC}_{\mathrm{TC}} /$ high power field. The net number of $\mathrm{MC}_{\mathrm{T}}$, containing only tryptase, was calculated by subtracting the number of $\mathrm{MC}_{\mathrm{TC}}$ from the total number of MCs. The average number of $\mathrm{MCs}, \mathrm{MC}_{\mathrm{TC}}$, and $\mathrm{MC}_{\mathrm{T}}$ per high power field in ten fields in each of the cortex and medulla were scored.

- Assessment of optical density of positively immune-stained mast cells in cortex and medulla to assess their granulation status. The image was first converted to grey-scale. The software was calibrated, using a standard grey scale, to convert pixel brightness values to optical density units. The image was then delineated (thresholded) to select only the areas exhibiting positive reactivity with accumulation of all grades of reactivity and the Mean Grey Value - average grey value within the selection - was calculated by the 
software and reported in calibrated optical density units.

\section{Statistical analysis:}

Data were presented as means \pm standard deviation (SD). Comparison within and between the two groups was carried out by student's $\mathrm{T}$ test. Results were considered significant when probability (p) was $\leq$ 0.05 , highly significant when $(p) \leq 0.01$ and very highly significant when $p \leq 0.001$ (Armitage and Berry, 1994).

\section{Results:}

\section{$\underline{\text { Histological results: }}$}

\section{Hematoxylin and Eosin \\ - Reproductive-age group:}

Examination of ovarian tissue of this group revealed that the ovary was covered by germinal simple cubical epithelium. The most superficial part of the cortex was covered by a capsule of interlacing bundles of fibrocyte-type cells and strands of eosinophilic collagenous fibrous tissue. Deep to this collagenous tissue, there was a layer of highly cellular basophilic stroma that consisted of interlacing bundles of closely packed elongated fibrocyte-type cells with elongated spindle-shaped nuclei (Plate 1A).

Occasional persistent primordial follicles were observed in the ovarian cortex, each formed of a large primary oocyte with a single layer of flat follicular granulosa cells (Plate 1B). Unilaminar primary follicles were found embedded in the cellular cortical stroma. Each was composed of a primary oocyte surrounded by a single layer of cuboidal granulosa cells (Plate 1C). Some multilaminar primary follicles with an oocyte surrounded by few layers of granulosa cells were also seen (Plate 1D). The pink-staining zona pellucida became evident between the oocyte and the granulosa cells. Condensation of the stromal cells around the follicles started to be noticed. Few secondary follicles, characterized by the appearance of fluid- filled cavity in-between the granulosa cells, were found. Their granulosa cell layer was thickened and the outer capsule of ovarian stromal cells showed a clear differentiation into two layers. The inner of which (theca interna) was formed of plumped cells with prominent capillaries in-between .The outer layer of stromal cells (theca externa) remained small and compact being formed of spindle-shaped cells (Plate 1E).

Corpora lutea were occasionally encountered in some of the studied ovarian specimens. They developed into defined lobes and convoluted walls. They were formed of large pale-staining vacuolated granulosa-lutein cells enclosing some capillaries in-between. Clusters of small compact theca-lutein cells were mainly concentrated along fibrous septa at the periphery of each corpus luteum (Plate 2A). Some atretic follicles with degenerating oocytes and collapsing zona pellucida were noticed (Plate 2B). Many corpora albicans were observed in the ovarian sections. They appeared as shrunken ovoid masses of relatively acellular hyaline collagenous tissue (Plate 2C). Ovarian medulla demonstrated less dense stromal cells but more blood vessels (Plate 2D).

\section{- Postmenopausal-age group:}

Examination of ovarian tissue of the postmenopausal-age group showed no evidence of any growing follicles in the ovarian cortex however many atretic follicles and corpora albicans were frequently detected. The ovarian surface was covered with simple squamous germinal epithelium (Plate $\mathbf{3} \mathbf{A} \boldsymbol{\&} \mathbf{B}$ ).

\section{Masson trichrome}

\section{- Reproductive-age group:}

Examination of the superficial part of the ovarian cortex revealed relatively less blue stained collagen fibers than the deeper part. Corpora albicans were occasionally found and were represented by irregular blue stained bodies of collagen fibers (Plate 3 C).

- The postmenopausal-age group: 
The cortical and medullary ovarian tissue exhibited more dark blue color occupying wider area of the examined sections with frequent corpora albicans (Plate 3 D).

\section{Immunohistochemical results:}

Positively immuno-stained mast cells for both proteases showed brown granular discoloration of their cytoplasm. The density of the color denoted the state of cytoplasmic granulation and hence variable grades of brown colour could be realized. The degranulating cells were also positively stained and showed a tail-like extracellular process due to positive immune-staining of the released granular contents between stromal cells (Plate 4).

\section{A) Tryptase Immunostaining:}

- The reproductive-age group:

In this group, mast cells positively labeled for tryptase were seen in the deep cortical stroma, in-between cells of degenerating corpora lutea and in the vicinity of blood vessels (Plate 5). No tryptase labeled mast cells were observed in the superficial cortical stroma, in the walls of the growing ovarian follicles or in corpora albicans (Plate 6).

\section{- The postmenopausal-age group:}

This group revealed the presence of perivascular tryptase positive mast cells which were seen also in-between stromal cells. There were no tryptase positive mast cells detected in the ovarian medulla (plate 7).

\section{B) Chymase Immunostaining:}

\section{- The reproductive-age group:}

This group revealed few densely stained chymase positive mast cells in the deep cortical stroma and in-between cells of the degenerating corpora lutea. On the other hand, no chymase immunostained mast cells were noticed in the superficial cortical stroma, in the walls of the primordial follicles, growing follicles and atretic follicles or in the degenerated corpus luteum (Plate 8 A\&B).
- $\quad$ The postmenopausal-age group:

This group showed few peri-vascular chymase labeled mast cells with less densely stained cytoplasm (Plate 8C). No chymase immunostained mast cells were observed in the walls of the different growing follicles, atretic follicles, cortical or medullary stroma. Few chymase positive mast cells were seen in the deep cortical stroma.

\section{Morphometric and Statistical results:}

The mean area percent of collagen in the reproductive-age group was greater in the medulla in comparison to the cortex. The recorded increase in the medullary values was statistically insignificant $(\mathrm{P}=0.06)$. However, these values showed an increase of statistical significance in the postmenopausal-age group $(\mathrm{P}=0.02)$. Data are represented in table (1) and histogram (1).

The reproductive-age group revealed statistically significant increased number of tryptase positive mast cells in comparison to chymase positive mast cells $(\mathrm{p}=0.001)$. There was also statistically significant increased number of tryptase positive mast cells in comparison to the number of chymase positive mast cells in the postmenopausal-age group $(\mathrm{p}=0.001)$. The number of tryptase positive mast cells in the reproductive-age group was statistically significant compared to the postmenopausal-age group $(\mathrm{p}=0.001)$. However, there was insignificant increase in the number of chymase positive mast cells in the reproductive-age group in comparison to the postmenopausal-age group $(\mathrm{p}=0.1)$. The total number of mast cells in the reproductive-age group showed statistically significant increase in comparison to that of the postmenopausalage group $(\mathrm{p}=0.001)$. These data are represented in table (2) and histogarm (2). Analysis of optical density of positively immunestained mast cells in both groups revealed significant higher values in tryptase-positive cells in comparison to 
chymase-positive cells in reproductive-age group $(\mathrm{P}=0.01)$. On the other hand, chymase-positive cells of postmenopausalage group showed higher values of statistical significance compared to the reproductive-age group $(\mathrm{P}=0.001)$. These data are represented in table (3) and histogarm (3).

Table (1): The mean \pm SD of the area per cent of the blue stained collagen in the ovarian cortex and medulla in both studied groups.

\begin{tabular}{|l|l|l|l|}
\hline Group Region & & & \\
\hline Reproductive-age group & Cortex & Medulla & P \\
\hline Postmenopausal-age group & $8.23 \pm \underline{ \pm 0.86}$ & $8.09 \pm 0.62$ & 0.06 \\
\hline
\end{tabular}

Significance was considered when $\mathrm{P} \leq 0.05$

*=Significant changes compared to the same group.

\# =Significant change compared to the other group.

Histogram (1): The mean area per cent of blue stained collagen in the ovarian cortex and medulla in both studied groups.

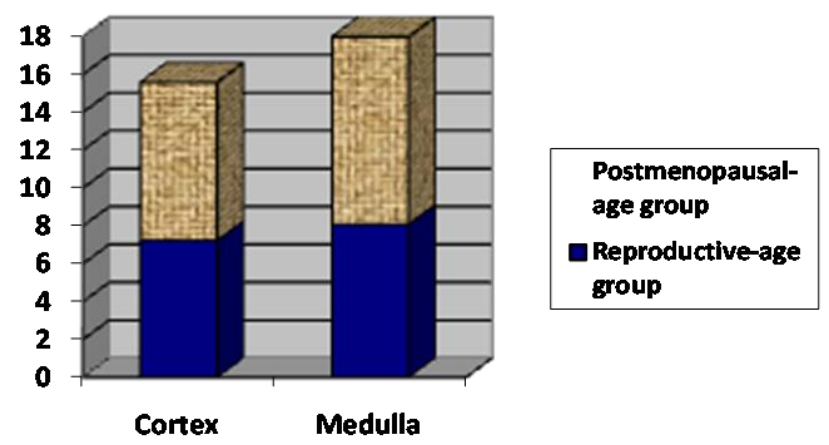

Table (2): The Mean number $+\mathrm{SD}$ of tryptase-positive mast cells $\left(\mathrm{MC}_{\mathrm{T}}\right)$, Chymase-positive mast cells $\left(\mathrm{MC}_{\mathrm{TC}}\right)$ and total mast cells (MCs) in ovarian tissue of both studied groups.

\begin{tabular}{|c|c|c|c|}
\hline $\begin{array}{ll}\text { cells } & \text { Type of mast } \\
\text { Group } & \end{array}$ & $\mathbf{M C}_{\mathrm{T}}$ & $\mathbf{M C}_{\mathrm{TC}}$ & Total MCs \\
\hline Reproductive-age group & $25.3 \pm 0.14 * \#$ & $7.8 \pm 0.96$ & $33.1 \pm 0.31 \#$ \\
\hline Postmenopausal-age group & $12.2 \pm 0.0 .65^{*}$ & $3.2 \pm 1.07$ & $15.4 \pm 1.28$ \\
\hline
\end{tabular}

Significance was considered when $\mathrm{P} \leq 0.05$

$*=$ Significant changes compared to the same group.

\# =Significant change compared to the other group. 
Histogram (2): The Mean number $+\mathrm{SD}$ of tryptase-positive mast cells $\left(\mathrm{MC}_{\mathrm{T}}\right)$, Chymase positive mast cells $\left(\mathrm{MC}_{\mathrm{TC}}\right)$ and total mast cells (MCs) in both studied groups.

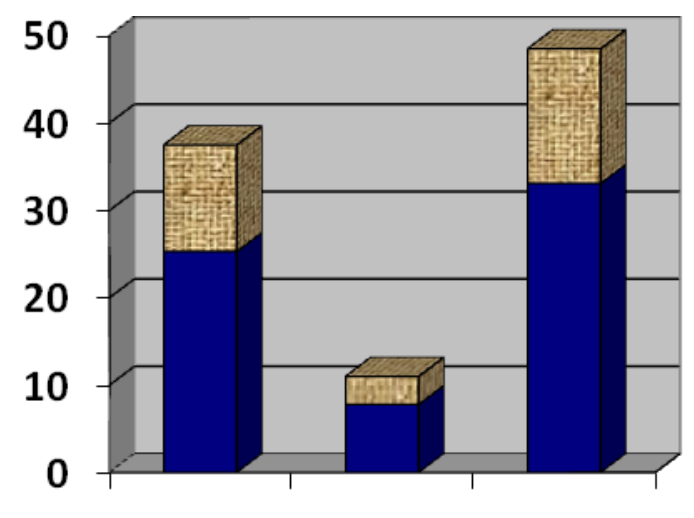

\begin{tabular}{l}
\hline Postmenopausal-age \\
group \\
Reproductive-age \\
group \\
\hline
\end{tabular}

MCT MCTC Total MC

Table (3): The mean $( \pm \mathrm{SD})$ optical density of $\mathrm{MC}_{\mathrm{T}}$ and $\mathrm{MC}_{\mathrm{TC}}$ in both studied groups.

\begin{tabular}{|l|l|l|}
\hline $\begin{array}{l}\text { cell } \\
\text { Group }\end{array}$ & & \\
\hline Reproductive-age group & $\mathbf{M C}_{\mathbf{T}}$ & $\mathbf{M C}_{\mathbf{T C}}$ \\
\hline Postmenopausal-age group & $0.3 \pm 1.50$ & $0.4 \underline{ \pm 0.21^{*}}$ \\
\hline
\end{tabular}

Significance was considered when $\mathrm{P} \leq 0.05$

*Significant changes compared to the same group.

\# Significant change compared to the other group.

Histogram (3): The Mean optical density of tryptase-positive mast cells $\left(\mathrm{MC}_{\mathrm{T}}\right)$ and Chymase positive mast cells $\left(\mathrm{MC}_{\mathrm{TC}}\right)$ in both studied groups.

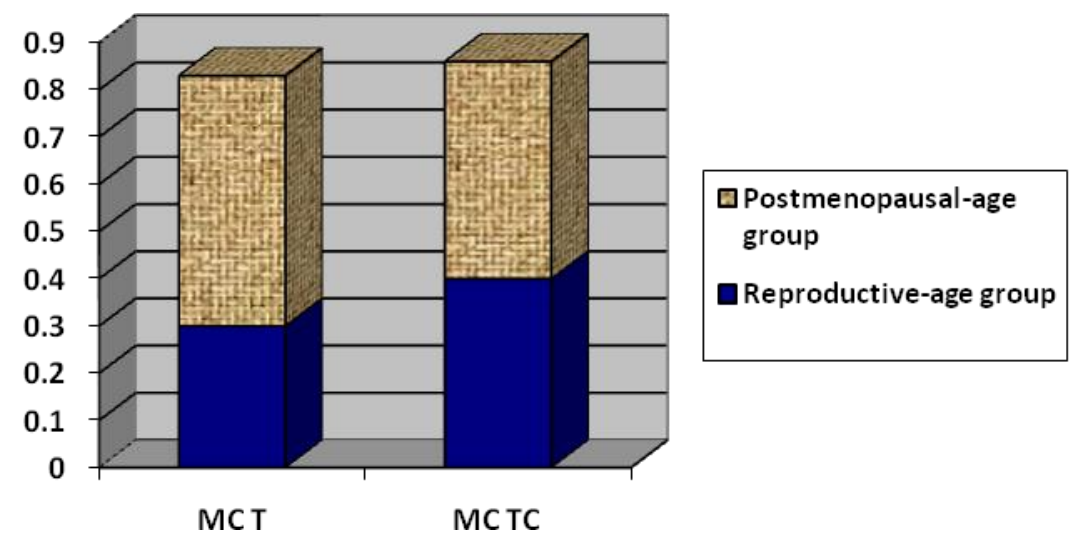



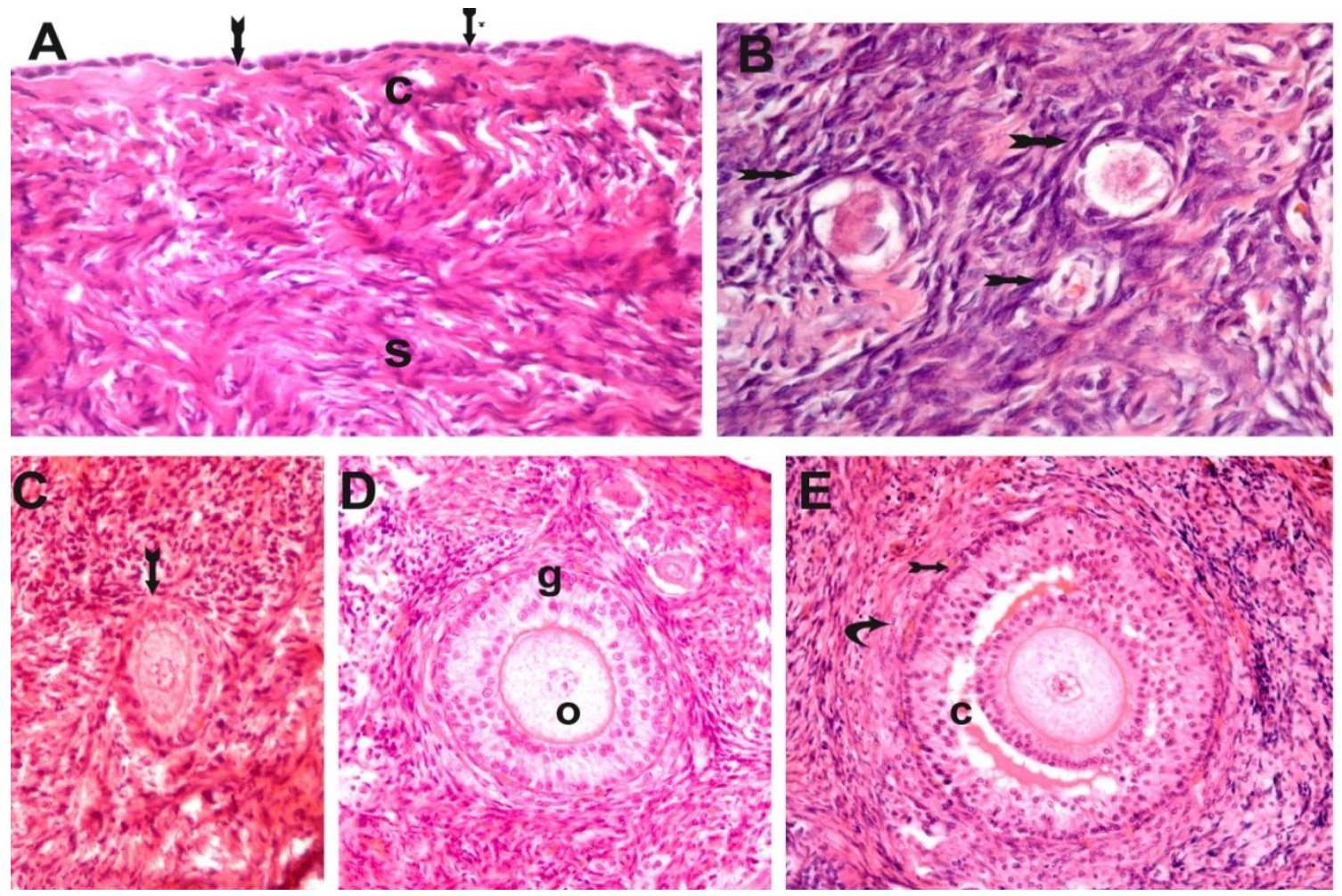

Plate 1: Photomicrographs of ovarian tissue of a female from the reproductive - age group stained with H\&E showing:

A. germinal simple cubical epithelium on the surface (arrows) covering the collagenous tissue of the capsule ( c) overlying a highly cellular basophilic stroma (s) (X400).

B. persistent primordial follicles (arrows) (X400).

C. unilaminar primary follicle (arrow)(X200).

D. multilaminar primary follicle with an oocyte $(\mathbf{o})$ surrounded by few layers of granulosa cells $(\mathbf{g})$ (X200).

E. secondary follicles with pink-staining zona pellucid (z) between the oocyte and the granulosa cells with fluid-filled cavity ( c). The outer capsule of ovarian stromal cells showed a clear differentiation into inner theca interna (arrow) and outer theca externa (curved arrow) (X200). 


\section{Sahar Gamal et al...}
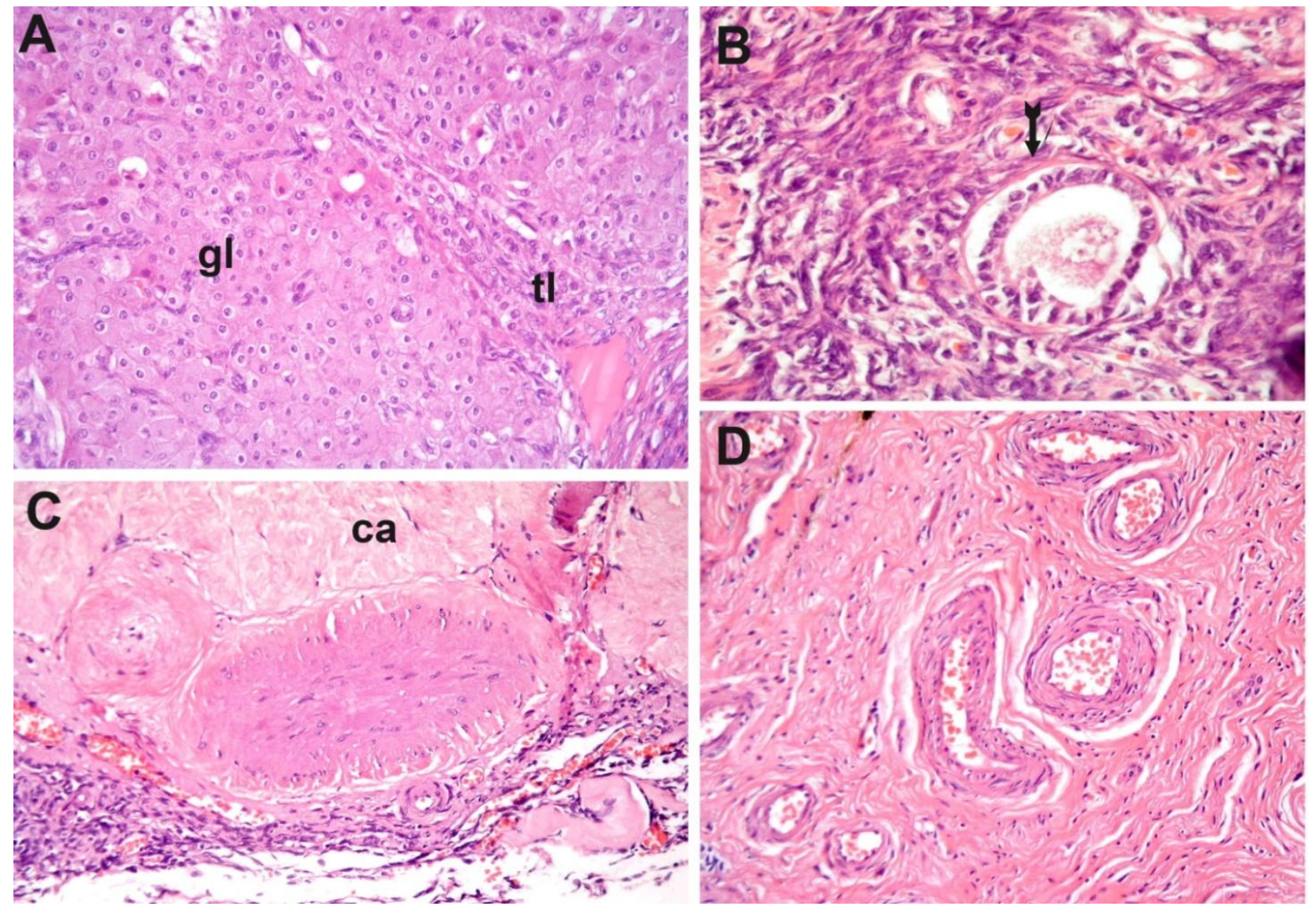

Plate 2: Photomicrographs of ovarian tissue of a female from the reproductive - age group stained with $\mathrm{H} \& \mathrm{E}$

A. peripheral part of one corpus luteum formed of large pale-staining vacuolated granulosa-lutein cells showing:

(gl) and Clusters of small compact theca-lutein cells (tl) present along fibrous tissue septum (X200).

B. atretic follicle (arrow) with degenerating oocyte and detached granulosa cells (X400).

C. A cellular hyaline collagenous tissue of corpus albicans (ca)(X200).

D. Ovarian medulla demonstrating less dense stromal cells and more blood vessels (X200). 

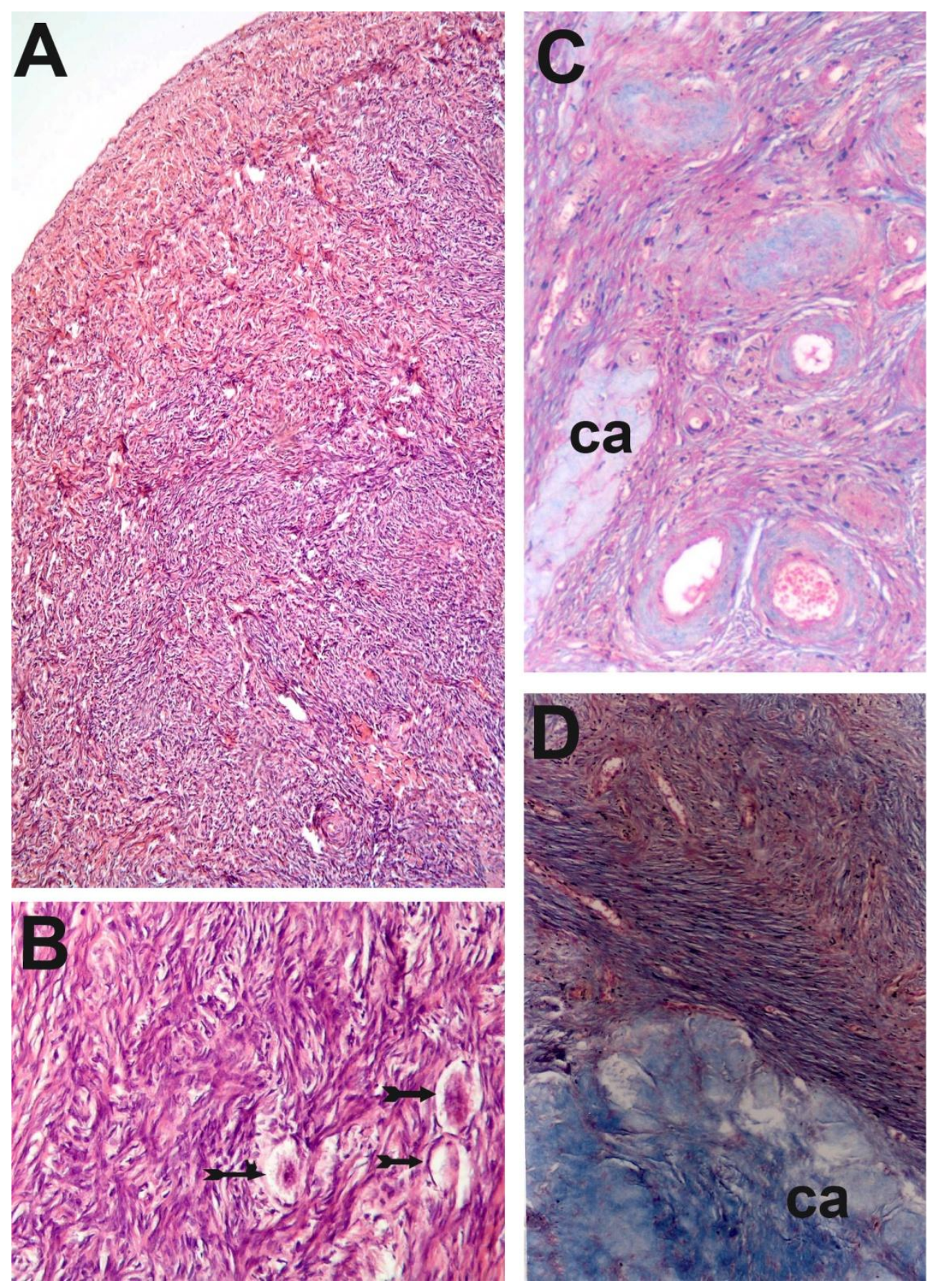

Plate 3: Photomicrographs of ovarian tissue of a female from the postmenupausal-age group (A,B and D) and the reproductive-age group $(\mathrm{C})$ showing:

A. ovarian surface covered by simple squamous germinal epithelium with no evidence of any growing follicles in the cortex (H\&E, X100).

B. frequent atretic follicles (arrows) (H\&E, X200).

C. collagen fibers in stroma and corpus albicans (ca) (M $\mathrm{T}, \quad \mathrm{X}$ 100). 


\section{Sahar Gamal et al...}

D. increased collagen fibers in stroma and corpus albicans (ca) (M T, X200).
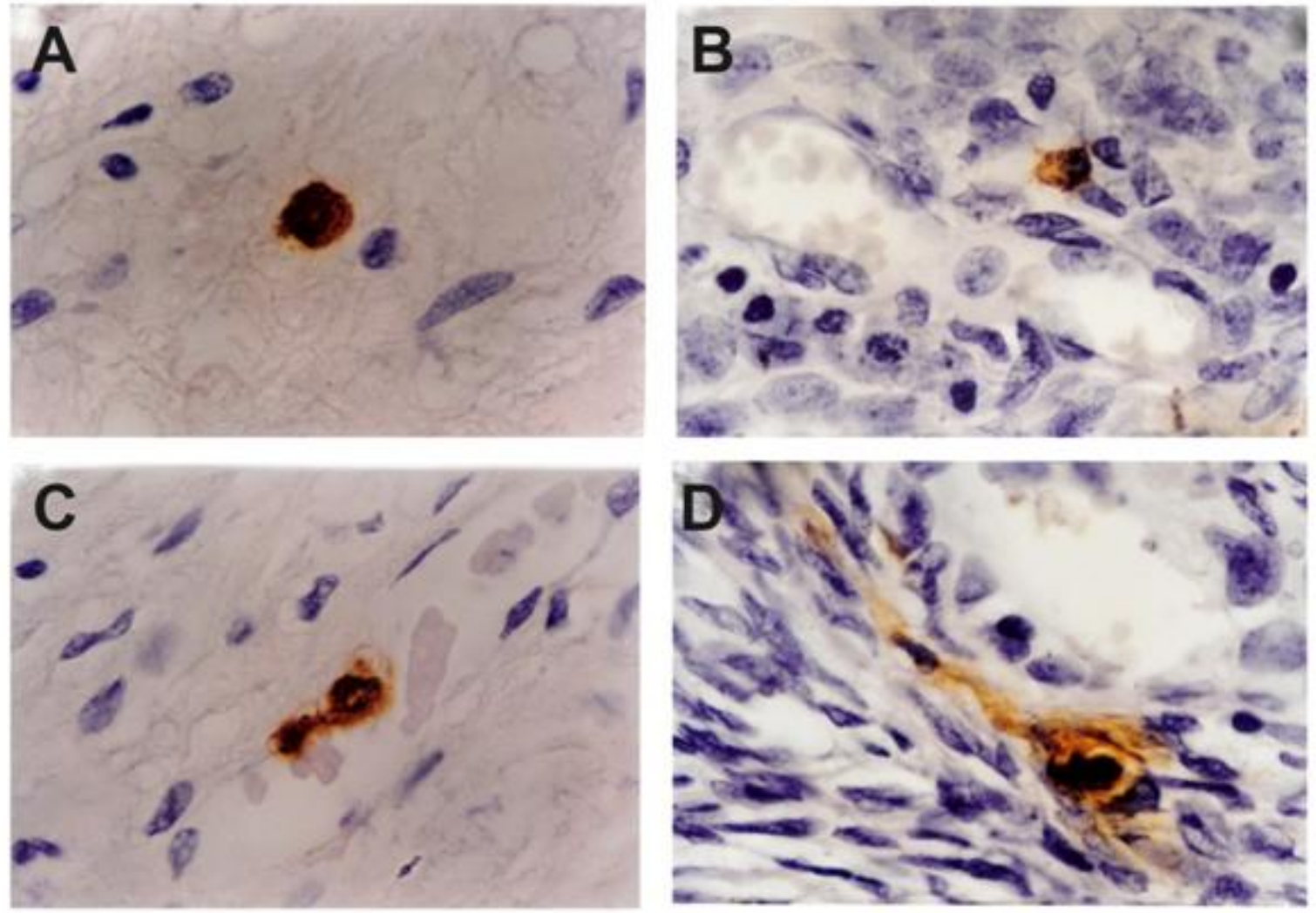

Plate 4: Photomicrographs of ovarian tissue of females from the reproductive-age group immunostained for tryptase (X1000) showing:

A. Densely stained mast cell with dark brown granular discoloration of its cytoplasm between medullary stromal cells.

B. Intermediatly stained mast cell in the vicinity of the blood vessel.

C. A mast cell about to leave a blood vessel.

D. degranulating mast cell with a tail-like extracellular process due to positive immune- staining of the released granular contents between stromal cells. 


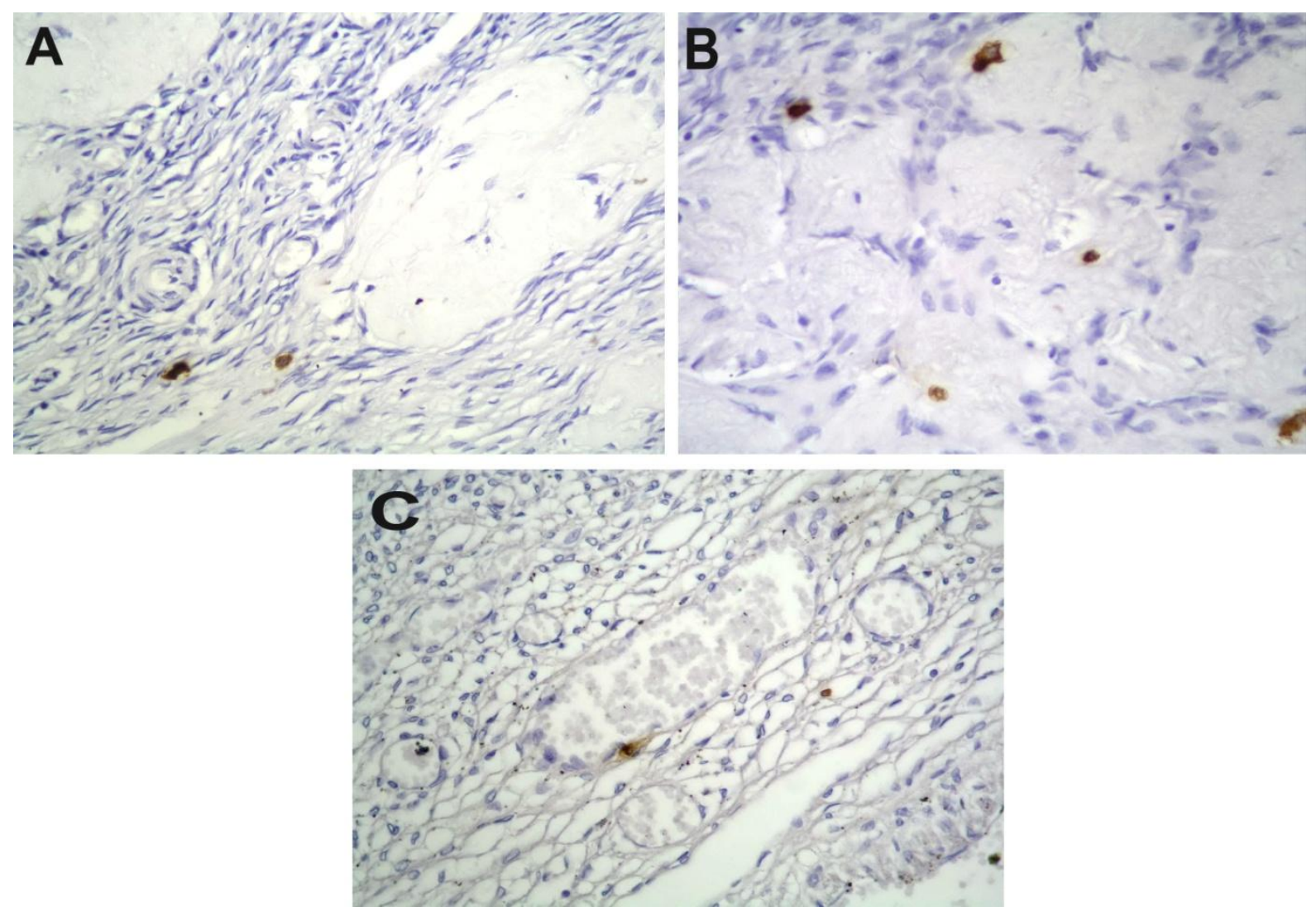

Plate 5: Photomicrographs of ovarian tissue of females from the reproductive-age group immuno-stained for tryptase (X400) showing mast cells positively labeled for tryptase seen in:
A. Deep cortical stroma.
B. In between cells of degenerating corpus luteum.
C. In the vicinity of blood vessels. 


\section{Sahar Gamal et al ...}
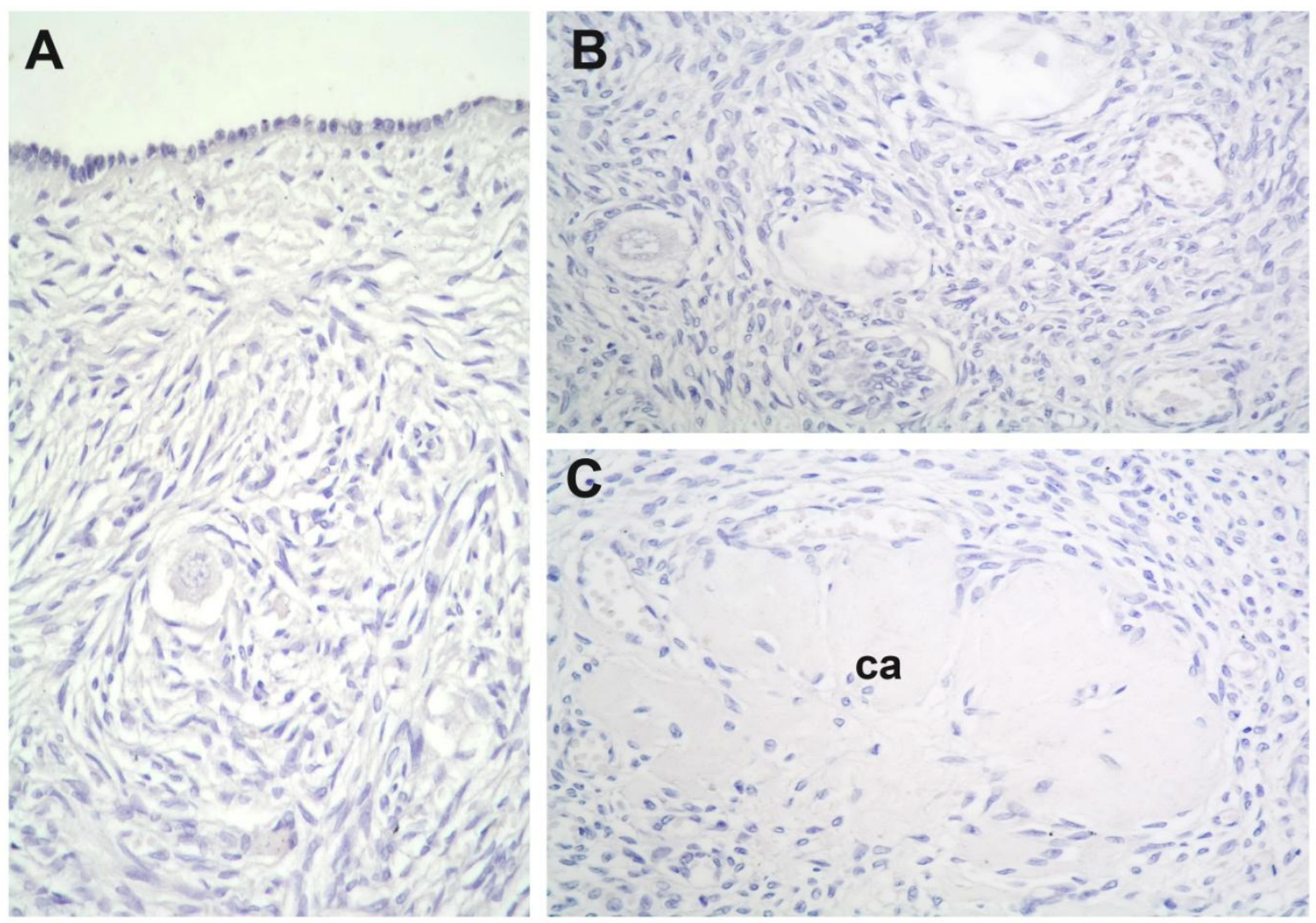

Plate 6: Photomicrographs of ovarian tissue of females from the reproductive-age group immuno-stained for tryptase (X400) demonstrating the absence of mast cells positively labeled for tryptase in:
A. superficial cortical stroma.
B. walls of the growing ovarian follicles.
C. in corpus albicans (ca). 

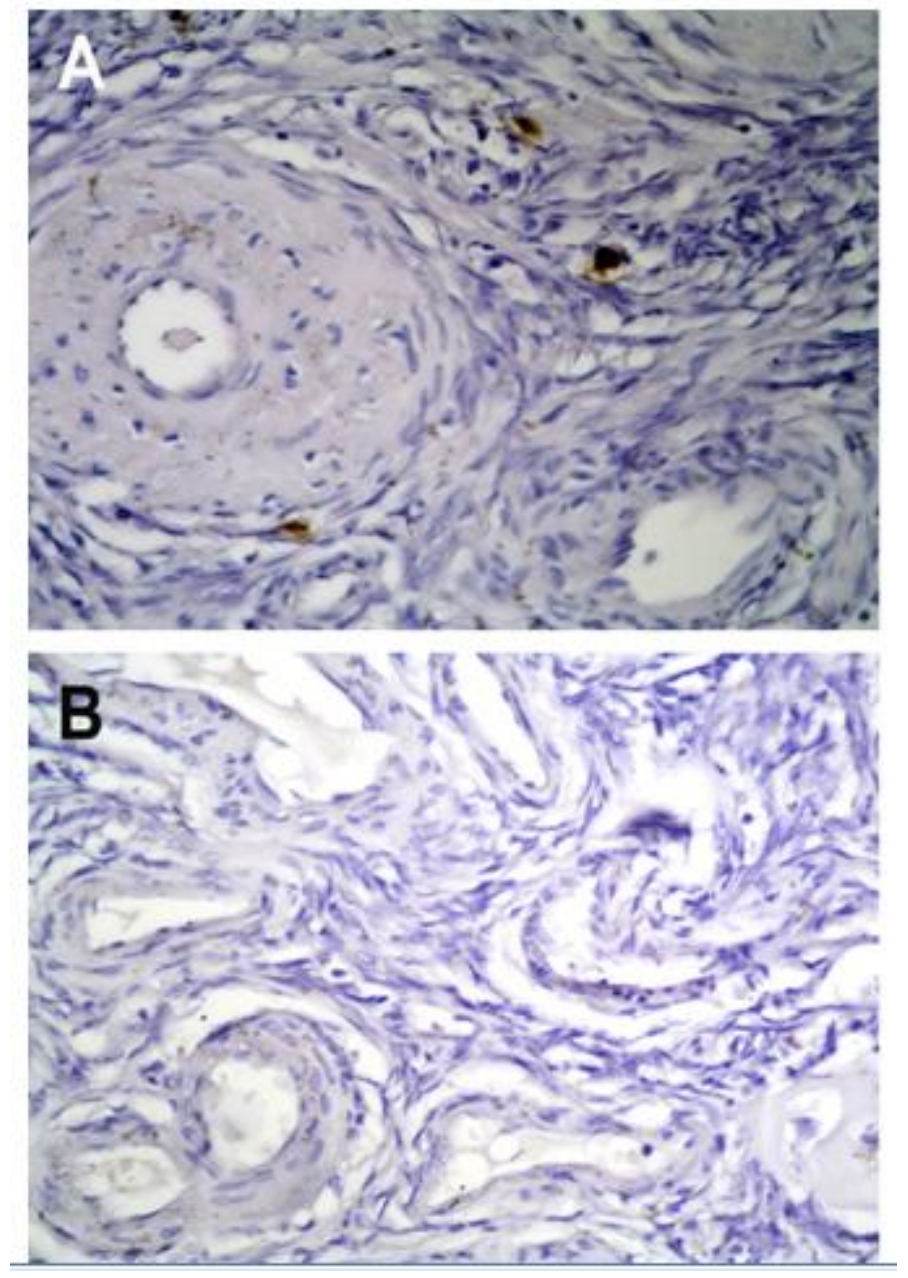

Plate 7: Photomicrographs of ovarian tissue of females from the postmenopausal-age group immunostained for tryptase (X400) demonstrating:

A. positively stained mast cells in-between stromal cells and nearby a blood vessel

B. no mast cells positively labeled for tryptase in the medulla. 

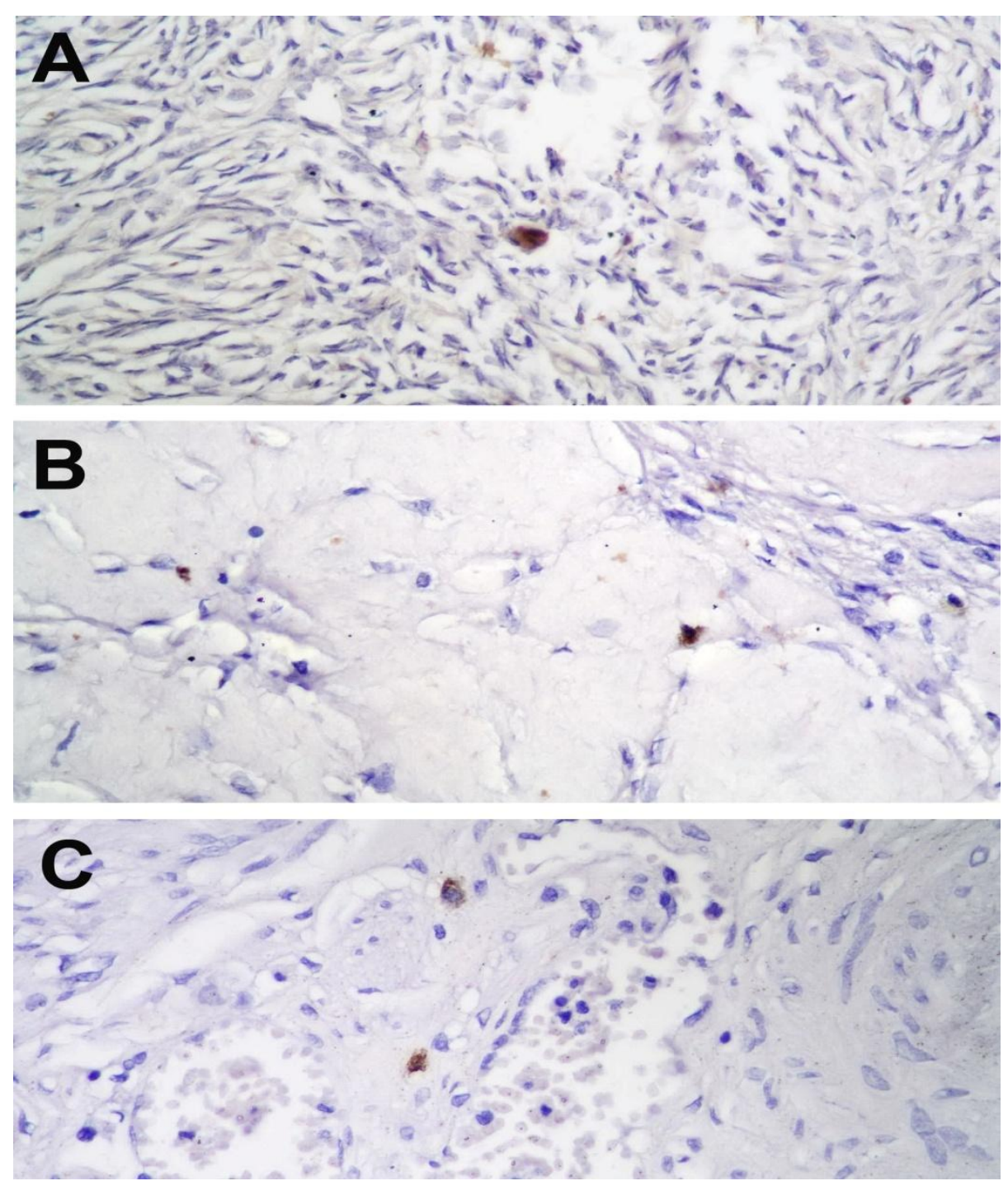

Plate 8: Three Photomicrographs of ovarian tissue of females immuno-stained for chymase (X400) demonstrating positively stained mast cell in deep cortical stroma (A) and in between cells of a degenerating corpus luteum $(\mathbf{B})$ in the reproductive-age group while in $(\mathbf{C})$, paravascular mast cells in a female of the postmenopausal-age group are evident.

N.B.: some of the mentioned original magnifications of the used photomicrographs were subjected to minor changes during preparation of the plates. 


\section{Discussion:}

The results presented in the current study emphasized the existence of the two subtypes of MC in human ovary during the reproductive and postmenopausal stages of human females lives. By using two monoclonal antibodies against tryptase and chymase, results of the present work revealed that MCs were neither detected in the periphery of the cortex nor within the walls of the ovarian follicles. MCs were observed mainly in the interstitial stroma of both deep cortex and medulla. In the medulla, most of the MCs were present in the connective tissue stroma in the vicinity of the blood vessels. These results were in accordance with previous studies performed by Reibiger and SpanelBorowski (2000) and Asuman et al. (2007) who reported that MCs were found in similar distribution in several mammalian species including humans.

The present results showed statistically significant more tryptase-positive mast cells than chymase-positive mast cells in the interstitial cortex and medulla of reproductive-age group in comparison to the postmenopausal-age group. This partially reinforced the results recorded by Heider et al. (2001) since they denied the presence of MCs in post menopausal ovaries. They could find alternatively a significant high density of nerve fibers and concluded that this decrease in mast cell population in postmenopausal ovaries may indicate an altered neuro-immune communication.

The mechanisms underlying these variations of MCs distribution were not clear. This could be attributed to a variety of possible mechanisms such as degranulation-regranulation patterns, cell death or cell migration (Karaca, et al., 2007). Earlier, this was explained only by migration of $\mathrm{MC}$ from extra-ovarian source, invasion or differentiation to maintain the requisite levels of histamine during ovulation (Kathpalia \& Parshad,
1990; Gaytan et al., 1991 and Batth and Parshad, 1996). Histamine has shown a stimulant effect on ovarian contractility, ovulation and follicular progesterone secretion (Krishna et al., 1989). Also, MCs may act as local modulator of steroid synthesis (Nottola et al., 2000).

Previously, MCs were known only to play a major role in allergic immune reactions. However, it has been shown recently that MC can affect many disciplines of intercellular communication. It was revealed after intensified research work that MCs have other domains to affect. They can play a significant role in a lifesaving host response to bacterial reaction (Malaviya and Georges, 2002), in tissue remodeling and fibrosis (Cairns and Walls, 1997), in angiogenisis (Blair et al., 1997) and may be even in cancer invasion (Samoszuk et al., 2005). Such heterogeneity is characterized by differences in their protease and cytokine content that was documented not only histochemically but also via electron microscopic findings. Bradding et al. (1995) found that $\mathrm{MC}_{\mathrm{T}}$ contain tryptase and some interleukins namely IL-4, IL-5 and IL-6. However, the other type $\mathrm{MC}_{\mathrm{TC}}$ contains tryptase, chymase, cathepsin G, carpoxypeptidase and IL-4. Electron microscopic studies revealed that $\mathrm{MC}_{\mathrm{T}}$ have secretory granules containing discrete scrolls, whereas $\mathrm{MC}_{\mathrm{TC}}$ have granules with grating and lattice substructures (Craig $\boldsymbol{e t}$ al., 1988).

Based on the observations that mast cell heparin is a powerful inhibitor of tumor growth in culture in presence of fibroblasts and that tryptase is strongly bound to heparin, Samoszuk et al. (2005) investigated the possibility of involvement of mast cells in suppression of tumor growth in tissues as well. They could find abundant degranulating mast cells in the peritumoral fibrous tissue. Consequently, they concluded that the stimulatory effect of mast cells on angiogenesis or fibroblasts or other functions within tumors might 
outweigh the inhibitory effects mediated by mast cell heparin and fibroblasts.

The detection of significant levels of tryptase in human semen and follicular fluid in addition to tryptase-positive mast cells in the human ovary and more specifically, in the wall of Fallopian tubes raised the issue that tryptase may exert regulatory actions on human spermatozoa. Weidinger et al. (2003) investigated this point and declared that tryptase significantly decreased normal human sperm motility in a dose- and timedependent manner. A recent study showed that epidermal growth factor receptor (EGF-R) and protease activated receptor 2 (PAR-2)-associated pathways are involved (Zitta et al., 2007).

The observations presented raise the possibility that tryptase directly interacts with human spermatozoa during their migration through the female genital tract. Genital tract mast cells and their products may be as yet unrecognized factors involved in human fertility disorders. On the other hand, Karaca et al. (2009) investigated the pre-implantation distribution of eosinophil granulocytes and mast cells (MCs) in the reproductive tract organs of female mammal and detected an increase in their numbers during this stage which is assumed to have its effect on the implantation results.

Localization of MCs deeper in the cortical stroma of the ovary might reflect that MCs affected fibrocyte organization and vascular permeability. Nottola et al. (2000) suggested that macrophages and mast cells may have a role as local modulators of steroid synthesis in the developing ovary. On the other hand, Fujiwara et al. (2004) and Samoszuk et al. (2005) suggested close relationship between mast cells, fibrosis and formation of adhesions.

In a former study, Asano-Kato et al. (2005) mentioned that tryptase producing MCs are the subtype to be incriminated in fibrosis observed in menopausal ovary. According to their observations, this hypothesis is supported by the predominance of $\mathrm{MC}_{\mathrm{T}}$ subtype in menopausal ovary as their data revealed which may directly result in increased fibroblast proliferation. The recognition of tryptase producing $\mathrm{MCs}$ in menopause might also help in more understanding of the cascade of events that could lead to early menopause. On the other hand, Yamanaka et al. (2000) reported that chymase-secreting MCs are the subtype to be incriminated in testicular fibrosis observed in subfertile males. The present data of this work pointed to the degranulation state of the two studied subtypes. The chymase positive cells exhibited low optical density denoting more degranulation of their protease in postmenopausal-age group and this may be correlated to their low detected number in that group. So, it could be assumed that degranulating $\mathrm{MC}_{\mathrm{TC}}$ can be responsible for the high collagen content in postmenopausal-age group

The development of MC subtypes depends on the specific tissue environment. $\mathrm{MC}_{\mathrm{T}}$ are the predominant subtype in the normal gastrointestinal mucosa, nasal mucosa and lung alveoli, whereas $\mathrm{MC}_{\mathrm{TC}}$ are the predominant subtype in gastrointestinal submucosa, nasal submucosa and skin (Gurish and Austen, 2002). A selective increase in $\mathrm{MC}_{\mathrm{T}}$ has been observed in the skin of patients with atopic dermatitis (Irani et al., 1990), in the nasal submucosa of patients with allergic rhinitis (Bentley $\boldsymbol{e t}$ al., 1992), and in cancer breast tissue (Kankkunen et al., 1997). On the other hand, an accumulation of $\mathrm{MC}_{\mathrm{TC}}$ has been found in the skin of the patients with mastocytosis, which is characterized by a lack of inflammatory infiltration (Irani $\boldsymbol{e t}$ al., 1990). These observations suggest that the $\mathrm{MC}_{\mathrm{T}}$ subtype is mainly involved in allergic and inflammatory responses while, the $\mathrm{MC}_{\mathrm{TC}}$ subtype is involved mainly in tissue remoudling and fibrosis (Welle, 1997). 
The present results reinforced the results of Batth and Parshad (2000) who reported that MCs were present among theca lutein cells of corpus luteum. They reflected the involvement of MCs products in the vascularization of corpora lutea. On the other hand, Karaca et al. (2008) recorded that MCs were not observed in the follicles, the corpus luteum and the underside of the surface epithelium of the ovarian cortex but they were observed in the cortical stroma and ovarian medulla. This is in accordance with the findings of the present work.

The present study revealed that some of the detected MCs tended to accumulate in the human ovary within the adventitia of the thick muscular arteries. This may indicate that these cells could influence the smooth muscle tone in the ovarian main arteries (Reibiger and Spanel-Borowski, 2000). Moreover, tryptase- and to a lesser extent chymase- can stimulate the matrix metalloproteinase (MMP-1) cascade responsible for tissue remodeling in ovary and postulated to have a potential role in breakthrough uterine bleeding (Milne et al., 2001).

\section{Conclusion:}

It is concluded that the variations in the number and type of proteases content of ovarian MCs in different age groups and in different ovarian components may reflect mutual regulatory mechanisms involving ovarian hormones and ovarian MCs that modulate the different ovarian functions of human ovary.

\section{Recommendation:}

It is recommended that further studies of the nature and contents of mast cells should be resumed specially in different parts of genital systems since this can reveal some of the mechanisms of unknown causes of fertility dysfunctions in both sexes.

\section{References:}

1. Armitage P and Berry G (1994): Statistical Methods in Medical Research, third edition, Blackwell Scientific Publications, London, pp. 40.

2. Asano-Kato N, Fukagawa K, Okada N, Dogru M, Tusbota $\mathbf{K}$, and Fujishima $\mathbf{H}$ (2005): Tryptase increases proliferation activity of human conjunctival fibroblasts through protease-activated receptor. Invest. Ophthalmol. Vis. Sci., 46(12):4622-4628.

3. Asuman O, Levent E, Emel E and Nejdet $S$ (2007): Morphological studies on ovarian mast cells in the caw. Turk. J. Vet. Anim. Soci; 31(2):131-136.

4. Batth $B$ and Parshad $R$ (1996): Quantitative assessment of changes and maturation of mast cells in the ovary of postnatal and adult rats, Rattus rattus. Indian journal of experimental biology, 34(7):692-699. 5. Batth B and Parshad R (2000): Mast cell dynamics in the house rat (Rattus rattus) ovary during estrus cycle, pregnancy and lactation. Eur. J. Morphol., 38(1):17-25.

6. Benoist C and Mathis D (2002): Mast cells in autoimmune disease. Nature, 420: 875-887.

7. Bentley AM, Jacobson MR and Cumberworth B (1992): Immunohistology of the nasal mucosa in seasonal allergic rhinitis increases in activated eosinophils and epithelial mast cells. J.Aller. Clin. Immun., 89: 821-829.

8. Blair R, Meng $H$ and Marchese M (1997): The human mast cells stimulate vascular tube formation: tryptase is a novel, potent angiogenic factor. J. Clin. Invest., 99: 26912701.

9. Bradding P, Okayama P, Howarth M, Church $K$ and Holgate $S$ (1995): Heterogenity of human mast cells based on cytokine content. J. Immunol., 155:297-310.

10. Cairns J and Walls F (1997): Mast cell tryptase stimulate the synthesis of type 1 collagen in human lung fibrosis. J. Clin. Inves., 99:1313-1319.

11. Craig S, Schechter $\mathbf{N}$ and Schwartz $\mathbf{L}$ (1988): Ultrastructural analysis of human $T$ and TC mast cells identified by immunoelectron microscopy. Lab. Invest., 58:682-690.

12. Drury RAB and Wallington EA (1967): Carleton's Histological Technique, $4^{\text {th }}$ ed., London, Oxford University press, New York, Toronto: Ridler, V. (pub). pp 114-117. 
13. Feldmann M, Morris $\mathbf{G}$ and Dinda P(1996): Mast cell mediate acids-induced augmentation of opossum esophageal blood flow via histamine and nitric oxide. Gastroenterology, 110:121-129.

14. Forsythe P and Ennis M (2000): Clinical consequences of mast cell heterogeneity. Inflamm. Res., 49:147-159.

15. Forsythe P and Befus D (2003): A Key to mast cell phenotypic and functional diversity. Amer.J. Resp. Molec. Biol. 28: 4005-4013.

16. Fujiwara H, Konno R, Netsu S, Sugamata M, Shibahara H, Ohwada M and Suzuki M (2004): Localization of mast cells in endometrial cyst. Am. J. Reprod. Immunol., 15(5):341-348.

17. Gaytan F, Aceitero J, Bellido C, Sanchez-Criado J and Aguilar E (1991): Estrous cycle-related changes in mast cell numbers in several ovarian compartments in rat. Biol. Reprod., 45(1):27-36.

18. Gurber B, Kew R and Jelaska A (1997): Human mast cells activate fibroblasts; tryptase is a fibrinogenic factor stimulating collagen messenger ribonucleic acid synthesis and fibroblast chemotaxis. J. Immunol., 158:23102318.

19. Gurish M and Austen K (2002): The diverse roles of mast cells. J. Exp. Med., 194: $1-5$.

20. Heider u, Pedal I and Spanel-Borowski K (2001): Increase in nerve fibers and loss of mast cells in polycystic and postmenopausal ovaries. Fertil. Steril. ,75(6):1141-1147.

21. Irani A, Garriga $M$ and Metcalfe $D$ (1990): Mast cells in cutaneous mastocytosis: accumulation of $\mathrm{MC}_{\mathrm{TC}}$ subtype. Clin. Exp. Allergy, 20: 53-59.

22. Kankkunen JP, Harvima IT and Naukkarinen A (1997): Quantitative analysis of tryptase and chymase containing mast cells in benign and malignant breast lesions. Int. J. Cancer, 72: 385-388.

23. Karaca T, Yoruk $M$ and Uslu $S$ (2007): Distribution and quantitative patterns of mast cells in the ovary and uterus of rat. Arch. MED. Vet., 39(2): 135-144.

24. Karaca T, Arikan S, Kalender $H$ and Yoruk M (2008): Distribution and heterogeneity of mast cells in female reproductive tract and ovary on different days of the oestrus cycle in Angora goats. Reprod. Domest. Anim., 18: 406-414.

25. Karaca T, Yörük M, Uslu S, Ģetin Y and Uslu BA (2009): Distribution of eosinophil granulocytes and mast cells in the reproductive tract of female goats in the preimplantation phase. Vet. Res. Comm., 33 (6): 545-554. [Printed on line on 31 January 2009].

26. Kathpalia K and Parshad R (1990): Mast cell dynamics in relation to ovulation in rat ovary. 28(3): 287-293.

27. Krishna A, Beesley $K$ and Terranova $P$ (1989): Hisamine, mast cells and ovarian function. J. Endocrinol., 120(3):363-372.

28. Malaviya $R$ and Georges A (2002): Regulation of mast cell-mediated innate immunity during response to bacterial infection. Clin. Rev. Allergy Immunol., 22:189198.

29. Meineke V, Fungieri M, Jessberger B, Vogt $H$ and Mayerhofer $A$ (2000): Human testicular mast cell contain tryptase: increased mast cell number and altered distribution in the testis of infertile men. Fertil. Steril., 74:239249.

30. Metcalfe D, Baram D and Mekori YA (1997): Mast cells. Physiol.Rev., 77: 10331039.

31. Milne SA, Rakhyoot A, Drudy TA, Brechin S, Riley SC and Critchley HOD (2001): Co-localization of matrix metalloproteinase-1 and mast cell tryptase in the human uterus. Mol. Hum. Rep., 7(6): 559565 .

32. Nottola S, Makabe S, Stallone T, Macchiarelli G, Correr $\mathbf{S}$ and Motta $P$ (2000): Ultrastructure and distribution of interstitial glandular cells and associated elements in human fetal ovaries. Arch. Histol. Cytol., 63(4): 345-355.

33. Reibiger $A$ and Spanel-Borowski $K$ (2000): Differences in localization of eosinophils and mast cells in the bovine ovary. J. Reproduction \& Fertility, 118: 243-249.

34. Rodewald HR, Dessing M, Dvorak AM and Galli SJ (1996): Identification of a committed precursor for mast cell lineage. Science, 271: 818-825.

35. Samoszuk M, Kanakubo E and Chan JK (2005): Degranulating mast cells in fibrotic regions of human tumors and evidence that mast cell heparin interferes with the growth of tumor cells through a mechanism involving fibroblasts. B.M.C. Cancer, 5: 121-134.

36. Weidinger A, Mayerhofer MB, Frungieri V, Meineke JR and Kohn FM (2003): Mast cell-sperm interaction: evidence for tryptase and proteinase-activated receptors in regulation 
of sperm motility. Human Reproduction, 18(12): 2519-2528.

37. Welle M (1997): Development, significance, and heterogeneity of mast cells with particular regard to mast cell-specific proteases chymase and tryptase. J. Leukoc. Biol., 61: 233-244.

38. Yamanaka K, Fujisawa M, Tanaka H, Okada H, Arakawa $\mathbf{S}$ and Kamidono $\mathbf{S}$ (2000): Significance of human testicular mast cells in male infertility. Hum. Rep., 15(7): 1543-1547.
39. Yong LC (1997): The mast cell: Origin, morphology, distribution and function. Exp. Toxicol. Pathol., 49: 409-424.

40.Zitta K, Albrecht M, Weidinger S, Mayerhofer A and Köhn F (2007): Protease activated receptor 2 and epidermal growth factor receptor are involved in the regulation of human sperm motility. Asian Journal of Andrology, 9: 690-696. 
Sahar Gamal et al...

\title{
توضيع و تصنيف الخلايا المتخمة في مبيض الاناث، دراسة هستولوجية و هنتوكيميائية مناعية
}

\author{
سحر محمد جمال، ناديه محمود الروبي و محمد عطية علي \\ قسم الهستولوجيا- كلية الطب- جامعة القاهرة
}

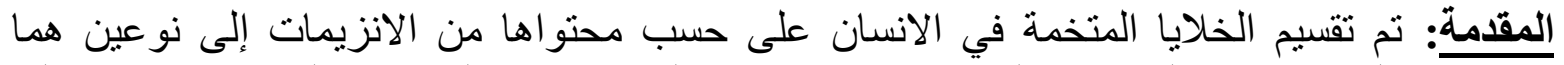
التى تحتوي على إنزيم التريبتيز و الانيان $\left(\mathrm{MC}_{\mathrm{T}}\right)$

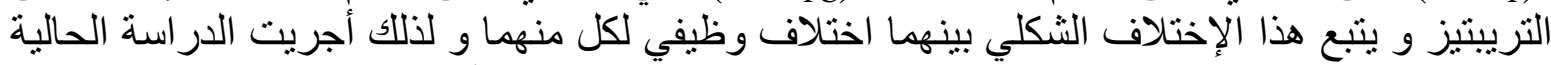

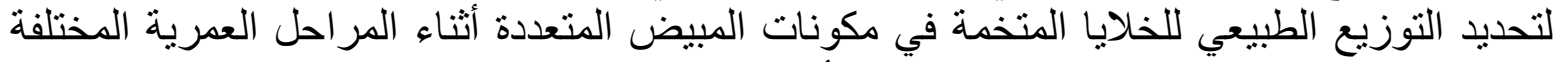

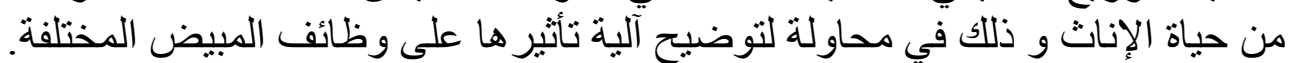

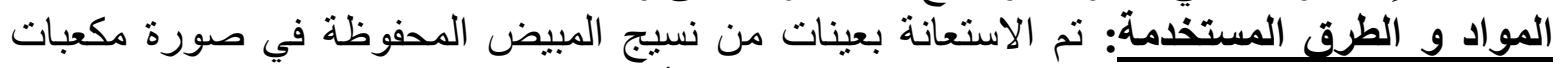

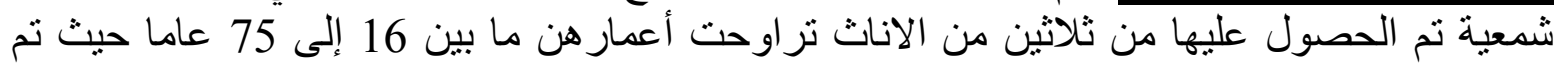

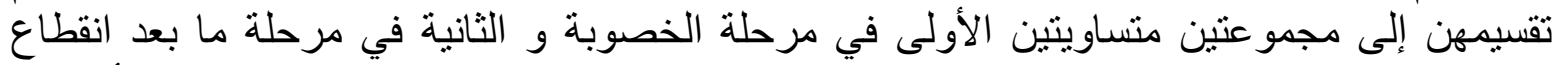

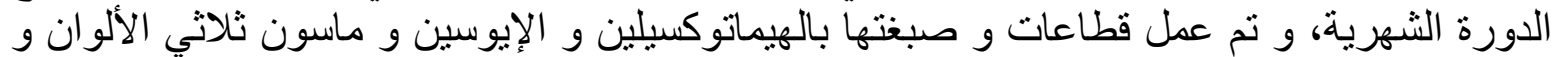

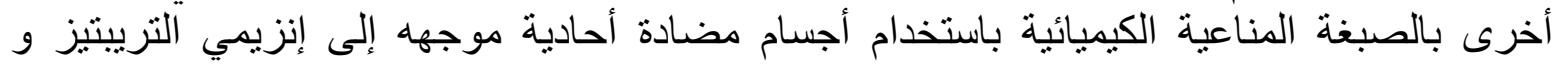

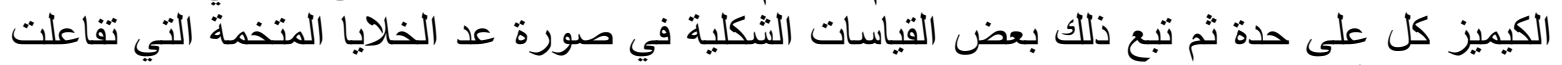

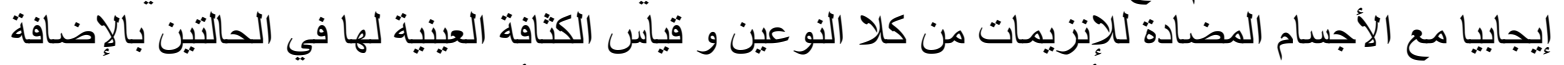
لقياس النسبة المئوية لمساحة ألياف الكو لاجين في المجمو عتين ثم أجري تحليل إحصائي للنتائج عن الإنان

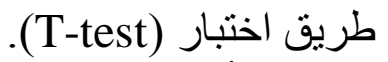

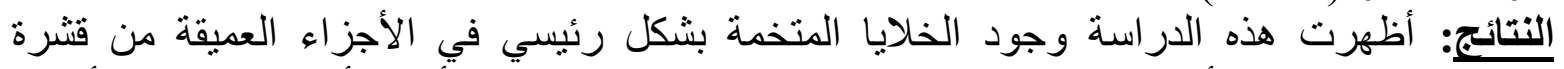

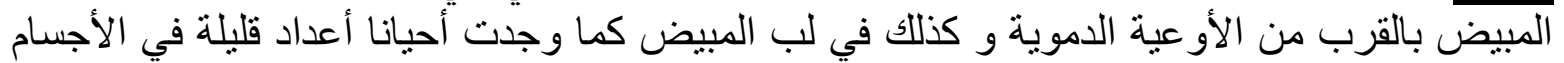

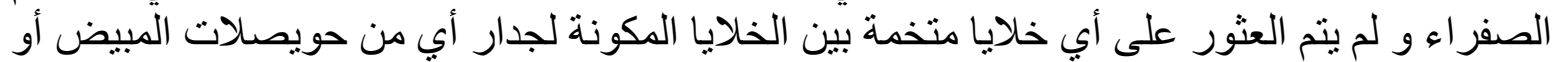

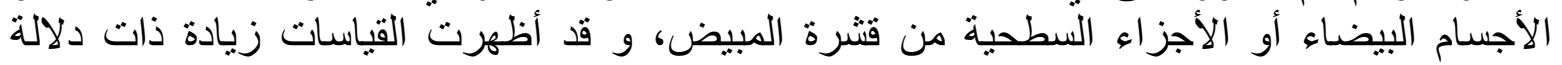

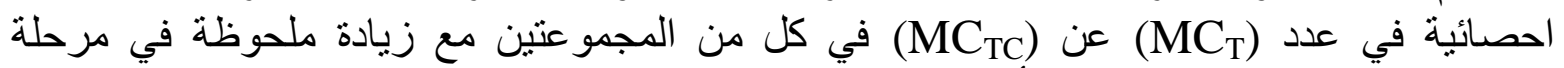

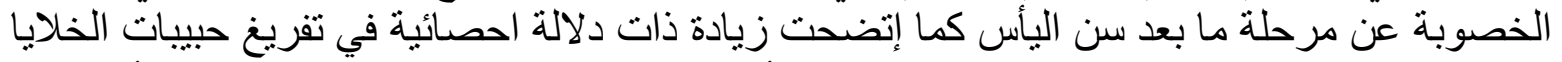

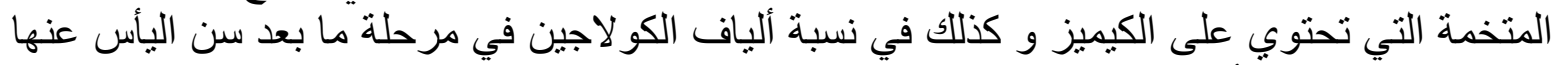

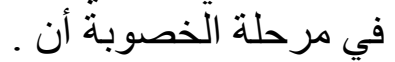
الأستتناج: يوجد توزيع يميز نوعي الخلايا المتخمة في المر احل العمرية المختلفة مما يشير إلى إمكانية

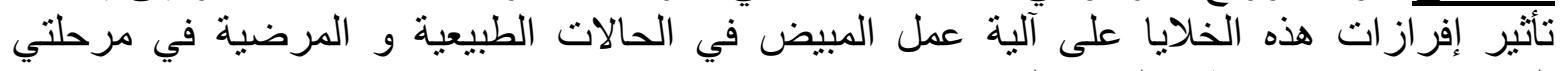
الخصوبة و ما بعد انقطاع الدورة الثهرية. 